\title{
Species Harvested, Wood Volume Removed, and a Rare Endemic Tree (Haptanthus) from a Honduran Lowland Forest
}

\author{
Donald L. Hazlett ${ }^{1}$
}

\begin{abstract}
For at least a century, the area of tropical American lowland forests has been in decline. One reason for this decline is logging. Logging operations in Honduras are rarely associated with botanical expeditions that identify the timber and non-timber species. This article documents the common and scientific names of trees harvested from a north-coast Honduran lowland forests from 1972-1979. During these nine years more than 50 tree species were harvested and more than $68,900 \mathrm{~m}^{3}$ of wood was extracted. The origins of the common names for many of the utilized timber trees are discussed. The most exploited trees were two species of Virola ( $V$. koschnyi and $V$. guatemalensis), which comprised more than $54 \%$ of the total extracted wood volume. In second place was Ceiba pentandra with more than $23 \%$ of the extracted wood. Huertea cf. cubensis and Sterculia mexicana trees were cut and utilized before they were known to occur in Honduras. A previously unknown endemic tree was collected from this logged area in 1980. This species has primitive angiosperm traits and was described as Haptanthus hazlettii (Buxaceae) in 1989. It was presumed to be extinct several decades, but was rediscovered in 2010. The original discovery, subsequent interest, and the current status of 44 known individuals of this endemic and endangered species are discussed. Primitive traits and the first complete taxonomic description (with fruits) for this taxon are included. Other little known native and endemic plants that occur in this region, especially species with ethnobotanical uses are discussed. The forest area removed in the 1970s is now very fragmented, which threatens the survival of endemic tree species.
\end{abstract}

Key words: Common names, Honduras, primitive angiosperm, scientific names, timber species, tropical deforestation.

\section{Especies Taladas, Volumen de Madera Extraído y un Árbol Endémico Raro (Haptanthus) de un Bosque Hondureño de Tierras Bajas}

Resumen. Por más de un siglo, el área de los bosques naturales en las tierras bajas de América tropical ha ido disminuyendo. Una de las razones es el aprovechamiento de la madera. En Honduras es poco común que la extracción de madera esté asociada con expediciones botánicas para identificar las especies maderables y no maderables. Este artículo es único porque documenta los nombres comunes y científicos de los árboles maderables aprovechados en un bosque hondureño entre 1972 y 1979. Durante estos 9 años, más de 50 especies de árboles fueron aprovechadas y más de $68,900 \mathrm{~m}^{3}$ de madera fueron extraídos. Los orígenes de los nombres comunes de unos árboles son discutidos. Los árboles más extraídos fueron dos especies de Virola ( $V$. koschnyi y $V$. guatemalensis) que sumaban el $54 \%$ del volumen de la madera extraída. En segundo lugar fue la Ceiba pentanda con más del $23 \%$ de la madera extraída. Huertea cf. cubensis y Sterculia mexicana fueron cortados y utilizados para madera antes de que fueran conocidos en la flora de Honduras. Un árbol endémico desconocido y raro fue recolectado por la primera vez en 1980 en esta zona. Esta especie tiene características de una angiosperma primitiva y fue descrita como Haptanthus hazlettii (Buxaceae) in 1989. Este árbol, que fue considerado extinto por varias décadas, fue recolectado de nuevo en el 2010. El descubrimiento original, el interés subsecuente y el estado actual de 44 individuos existentes de este árbol son discutidos. Este artículo también resume las características primitivas e incluye la primera descripción botánica completa (con frutos) de esta especie monotípica endémica en peligro crítico de extinción. Otras plantas endémicas de esta zona que son poco conocidas, especialmente especies con usos etnobotánicos están discutidas. El bosque aprovechado en la década de 1970 muy fragmentado. Por lo tanto, la sobrevivencia de muchas especies endémicas de esta zona está amenazada.

Palabras clave: Angiosperma primitiva, árboles maderables, deforestación tropical, Honduras, nombres científicos, nombres comunes.

${ }^{1}$ Denver Botanic Gardens, 1007 York St., Denver, Colorado, 80206, United States. E-mail: Newworldplants@gmail.com

DOI: 10.5377/ceiba.v53i2.2506 


\section{Introduction}

Tropical lowland forests in Latin America have been disappearing at a rapid rate for decades (Grainger 1993). Estimates for deforestation in Honduras for 1976-1980, 1982, 1981-1985, and 19811990 are 53,000, 70,000, 90,000, and 112,000 ha per year, respectively (Kaimowitz 1996). Deforestation estimates in Honduras from 2000 and 2005 average 47,200 ha per year. This calculates to a $37 \%$ reduction in Honduran forest cover between 1990 and 2005 (Butler 1994-2006). In 2000, the amount of primary forest remaining in Honduras was 1.51 million hectares or $14 \%$ of the total Honduran land area.

Reasons for deforestation in Honduras include clearing land for cattle pastures, African oil palm plantations, firewood, mining, fire, and timber exploitation. Many other Honduran lowland forests have been exploited for timber, especially for quality wood from mahogany (Swietenia macrophylla), Spanish cedar (Cedrela odorata), and rosewood (Dalbergia spp.). This article documents timber species utilized for plywood by TIMSA (Tela Industrial Maderera S.A.) between 1972 and 1979. This is the greatest diversity of tree species ever reported as extracted and utilized for a single logging operation in Honduras.

The common names, scientific names, and volume of wood utilized are reported. The origins of tree common names for many timber and non-timber tree species present in the logged areas are discussed. Also included are ethnobotanical uses for native tree that occur in the logged forest area.

A previously undescribed, non-timber tree species discovered in the logged area, was of special interest. This is an enigmatic and primitive angiosperm tree that was first collected in 1980, described as Haptanthus hazlettii in 1989, presumed to be extinct for two decades, and rediscovered in 2010. Information about Haptanthus, from its initial discovery to current monitoring efforts, are summarized.

\section{Background}

Between 1972 and 1981, a French-owned plywood company called TIMSA (Tela Industrial
Maderera S.A.) secured a concession to selectively remove timber trees from extensive areas of primary forest in lowland areas (200-1000 m elevation) along the Honduran north coast. This large, poorly defined area of exploitation was located east of Tela, extended at least halfway toward La Ceiba, and was mostly north of the higher elevations of the Cordillera Nombre de Dios. The majority of this area was in the Atlántida Department, but access roads sometimes entered the more southern Department of Yoro. Southern portions of the TIMSA harvested area are now included, or at least border, a protected area called Refugio de Vida Silvestre Texiguat (Texiguat Wildlife Refuge).

The president of the TIMSA plywood factory in the late 1970s was Pierre Ligeard (Don Pedro). I began work at the Lancetilla Botanical Garden in 1978, a few years after the TIMSA logging operation began. I recognized the unique opportunity to collect plants from this actively logged primary forest. I met with Don Pedro to request permission to collect plant specimens in the logged area. As long as I did not interfere with the logging operations, they allowed me to use the access roads to enter the forest and to make plant collections.

I also asked Don Pedro if his tree-finders had experience identifying local tree species. He was not in touch with any of the tree finders. When I eventually met these men, I learned that only a few had treefinding experience prior to their work with TIMSA. These few served as mentors for other members of the harvest crew.

Don Pedro complained of the lack of forest inventory information from the forests he had permission to exploit. Without inventory data, TIMSA did their own log-peel tests to determine which species were appropriate for plywood. TIMSA was not concerned with scientific names, but did keep records on the common names and sizes of the extracted tree species. A large number of trees were felled for access, but were not extracted. I was fortunate that an administrator gave me a copy of the common names and volumes of the trees harvested by TIMSA from 1972-1979 (Tables 1 and 2). The TIMSA harvest operation continued into the 1980 s, but I was unable to secure timber harvest data after 1979. 
Hazlett: Species Harvested, Wood Volume Removed, and a Rare Endemic Tree (Haptanthus)

Table 1. The volumes and names for the 19 most frequently tree species harvested by TIMSA (Tela Industrial Maderera S.A.) from 1972 to 1979 . These species had at least $100 \mathrm{~m}^{3}$ of wood extracted over 8 years. Scientific names with an asterisk were not verified with botanical specimens. Data provided by TIMSA.

\begin{tabular}{|c|c|c|c|c|c|c|c|c|c|}
\hline $\begin{array}{l}\text { Timber Species } \\
\text { Scientific \& Common Name }\end{array}$ & 1972 & 1973 & 1974 & 1975 & 1976 & 1977 & 1978 & 1979 & $\begin{array}{c}\text { Total }\left(\mathrm{m}^{3}\right) \\
-(\% \text { of } \\
\text { total })\end{array}$ \\
\hline $\begin{array}{l}\text { Virola koschnyi Warb. \& Virola } \\
\text { guatemalensis (Hemsl.) Warb. } \\
\text { caobina, sangre }\end{array}$ & 1,174 & 5,739 & 2,889 & 5,021 & 6,782 & 4,836 & 5,491 & 5,084 & $37,016-54$ \\
\hline $\begin{array}{l}\text { Ceiba pentandra (L.) Gaertn. } \\
\text { ceibo }\end{array}$ & 36 & 740 & 1,109 & 1,012 & 794 & 1,957 & 2,907 & 5,809 & $14,364-23$ \\
\hline $\begin{array}{l}\text { Sterculia mexicana R. Br. } \\
\text { guanillo }\end{array}$ & 2 & 493 & 424 & 579 & 243 & 686 & 730 & 843 & $4,000-6-7$ \\
\hline $\begin{array}{l}{ }^{*} \text { Mortoniodendron anisophylum } \\
\text { (Standl.) Standl. \& Steyerm. } \\
\text { barrenillo }\end{array}$ & 4 & 185 & 391 & 589 & 74 & 290 & 213 & 299 & $2,045-3-4$ \\
\hline $\begin{array}{l}\text { Cordia alliodora (Ruiz \& Pav.) } \\
\text { Oken } \\
\text { laurel }\end{array}$ & 0 & 249 & 3 & 248 & 301 & 251 & 129 & 68 & $1,249-2-3$ \\
\hline $\begin{array}{l}\text { *Eschweileria hondurensis Standl. } \\
\text { cuero de toro }\end{array}$ & 0 & 25 & 0 & 540 & 148 & 237 & 194 & 57 & $1,200-1-2$ \\
\hline $\begin{array}{l}\text { Schizolobium parahyba (Vell.) } \\
\text { S.F. Blake } \\
\text { Zorra }\end{array}$ & 0 & 134 & 0 & 0 & 141 & 309 & 282 & 225 & $1,091-1-2$ \\
\hline $\begin{array}{l}\text { Gordonia fruticosa (Schrad.) H. } \\
\text { Keng } \\
\text { Azajarillo }\end{array}$ & 0 & 0 & 0 & 57 & 23 & 114 & 717 & 100 & $1,011-1-2$ \\
\hline $\begin{array}{l}\text { Calophyllum brasiliense Cambess } \\
\text { María, Santa María }\end{array}$ & 0 & 138 & 0 & 150 & 118 & 366 & 74 & 8 & $854-1-2$ \\
\hline $\begin{array}{l}\text { Hyeronima alchorneoides Allemño } \\
\text { curtidor, nance de montaña }\end{array}$ & 0 & 118 & 0 & 389 & 54 & 83 & 76 & 103 & $823-1-2$ \\
\hline $\begin{array}{l}\text { Simarouba amara Aubl. } \\
{[=S \text {. glauca }]} \\
\text { negritón, aceituno }\end{array}$ & 2 & 78 & 0 & 0 & 0 & 183 & 173 & 245 & $681-1-2$ \\
\hline $\begin{array}{l}\text { Pinus caribaea Morelet } \\
\text { Pino }\end{array}$ & 0 & 0 & 0 & 124 & 45 & 28 & 474 & 0 & $671-1-2$ \\
\hline $\begin{array}{l}\text { Vochysia guatemalensis Donn } \\
\text { Sm. } \\
\text { San Juan }\end{array}$ & 10 & 103 & 0 & 13 & 0 & 264 & 101 & 133 & $624-<1$ \\
\hline $\begin{array}{l}{ }^{*} \text { Tapiriira guianensis Aubl. } \\
\text { piojo, mata piojo }\end{array}$ & 0 & 31 & 0 & 9 & 10 & 170 & 106 & 5 & $331-<1$ \\
\hline $\begin{array}{l}\text { Swietenia macrophylla King } \\
\text { caoba }\end{array}$ & 0 & 291 & 0 & 0 & 0 & 3 & 0 & 0 & $294-<1$ \\
\hline $\begin{array}{l}\text { Macrohasseltia macroterantha } \\
\text { (Standl. \& L.O. Williams) } \\
\text { L.O. Williams } \\
\text { tempisque, hoja ancha }\end{array}$ & 0 & 20 & 0 & 4 & 15 & 151 & 43 & 0 & $233-<1$ \\
\hline $\begin{array}{l}\text { Huertea cf. cubensis Griseb. } \\
\text { cedrillo }\end{array}$ & 0 & 21 & 0 & 127 & 10 & 22 & 24 & 12 & $216-<1$ \\
\hline $\begin{array}{l}\text { Cedrela odorata } \mathrm{L} . \\
\text { cedro, cedro real }\end{array}$ & 0 & 105 & 0 & 14 & 0 & 0 & 0 & 0 & $119-<1$ \\
\hline $\begin{array}{l}\text { Vochysia ferruginia Mart. } \\
\text { San Juan de costa }\end{array}$ & 10 & 37 & 55 & 0 & 0 & 0 & 0 & 0 & $102-<1$ \\
\hline Mix of ca. 25 taxa (Table 2 ) & 9 & 418 & 0 & 220 & 340 & 362 & 627 & 16 & $1,992-3-4$ \\
\hline Totals $\left(\mathrm{m}^{3}\right)$ & 1,247 & 8,925 & 4,871 & 9,096 & 9,098 & 10,312 & 12,361 & 13,007 & 68,916 \\
\hline
\end{tabular}


Table 2. The volumes and names for about 25 taxa of trees that were infrequently harvested in 1973 . This was a year when unidentified trees were tested for possible use as plywood and was the only year when common names and volumes were available for little-utilized species. The volume of little-utilized trees in 1973 was about $30 \%$ of $1,992 \mathrm{~m}^{3}$, the total volume of infrequently harvested timber (Table 1). Scientific names with an asterisk were not verified with botanical specimens. Data provided by TIMSA (Tela Industrial Maderera S.A.).

\begin{tabular}{|c|c|c|}
\hline Scientific Name or Family & Common Name & $\mathbf{m}^{3}$ \\
\hline Nectandra / Ocotea / Persea & aguacatillo, aguacate del monte & 80.5 \\
\hline Vatairea lundellii (Standl.) Killip ex Record & amargoso & 58.1 \\
\hline Brosinium alicastrum Sw. & masica & 48.9 \\
\hline Podocarpus oleifolius D. Don ex Lam. & ciprés & 41.2 \\
\hline Bursera simaruba (L.) Sarg. & indio desnudo & 27.4 \\
\hline${ }^{*}$ Gordonia brandegeei $\mathrm{H}$. Keng & cuero de toro & 25.1 \\
\hline Symphonia globulifera L. f. & barillo, varillo & 24.0 \\
\hline Unidentified & retintón & 19.1 \\
\hline *Ampelocera hottlei (Standl.) Standl. & manteco & 17.8 \\
\hline Jacaranda copaia (Aubl.) D. Don & tambor & 16.2 \\
\hline Guarea glabra Vahl or G. grandifolia DC. & carbón & 15.7 \\
\hline Tetrorchidium rotundatum Standl. & San Juan Guayapeño & 13.1 \\
\hline Zanthoxylum sp. & cedro espino & 10.6 \\
\hline Unidentified & opiojante & 10.2 \\
\hline $\begin{array}{l}\text { Byrsonima crassifolia (L.) Kunth or *Hyeronima oblonga (Tul.) } \\
\text { Müll. Arg. }\end{array}$ & nance del monte & 9.6 \\
\hline Cupania glabra Sw. & cola de pavo & 9.3 \\
\hline Ficus sp. & higuero & 4.7 \\
\hline Unidentified Sapotaceae & gigante & 4.5 \\
\hline Manilkara sp. or Pouteria sp. & níspero & 4.1 \\
\hline Unidentified & ocotillo & 3.9 \\
\hline Juglans sp. & nogal & 3.0 \\
\hline Unidentified Sapotaceae & zapotón & 2.0 \\
\hline Spondias mombin L. & jobo & 2.0 \\
\hline Terminalia amazonia (J.F. Gmel.) Excell in Pulle & naranjo & 2.3 \\
\hline Ilex discolor Hemsl. & guayabillo, limoncillo & 1.0 \\
\hline Subtotal: wood volume harvested in 1973 only & & 454.3 \\
\hline
\end{tabular}




\section{Methods}

TIMSA provided lists of tree common names and cubic meter amounts of trees that arrived to the plywood factory between 1972 and 1979. Five trips to the logged area were made in 1979 and 1980 (March to May) to collect plant material in order to verify the scientific names for the common names on TIMSA lists (Tables 1 and 2). In addition, plant material was collected from other tree species discovered in the logged areas.

\section{Results}

TIMSA knew from the onset that Virola was excellent for plywood, but had little reliable information about other native trees that could be used for plywood. In search for additional logs, at least 50 species were harvested, transported to the factory, and peeled. This trial-and-error method identified six species as the most available and suitable for plywood - the first six species listed on Table 1. These six species comprised nearly $90 \%$ of the $68,916 \mathrm{~m}^{3}$ of wood extracted from these forests from 1972 to 1979 (Table 1).

The TIMSA factory created a pile of harvested trees that were deemed as unsuitable for plywood. Among these were trees with valuable wood, such as granadillo or rosewood (Dalbergia spp.) and paleto (Dialium guianensis). There was no sawmill or market available for these native hardwood trees. No records were kept of the species or for the number of trees (dozens were seen in piles) that were extracted from forests and transported to the plywood factory -only to be discarded as unsuitable for plywood.

The most sought after and harvested trees were Virola koschnyi and V. guatemalensis (Myristicaceae). Over half of the total wood volume extracted over 8 years was from these two species (Table 1). The wood from both of these Virola species is similar. This wood, with a density in the range of $0.40-0.48 \mathrm{~g} / \mathrm{cm}^{3}$, works well for plywood, and dries to a rich brown color. The in-roads into the primary forest were, in large part, arranged to access areas with clusters of large Virola trees. Virola koschnyi trees, the most common of the two species, were more common at lower elevations. The less frequently harvested $V$. guatemalensis was more common at higher elevations. TIMSA did not distinguish which Virola species was harvested. Some of the trees may also have been Virola sebifera Aubl.
Virola species were easily identified due to their red sap (Figure 1), the reason for the common name sangre (blood). In 1979, Virola seeds were collected from the logging areas and were planted into the Lancetilla arboretum. In 2015, Virola guatemalensis, planted in 1979, was growing and had a diameter of 21 $\mathrm{cm}$ (ca. 8 inches), a diameter increment of about 0.6 $\mathrm{cm}$ per year. The Virola trees harvested were often over $1.0 \mathrm{~m}$ in diameter (Figure 1). It is estimated that many of the Virola trees harvested by TIMSA were at least 200 years old.

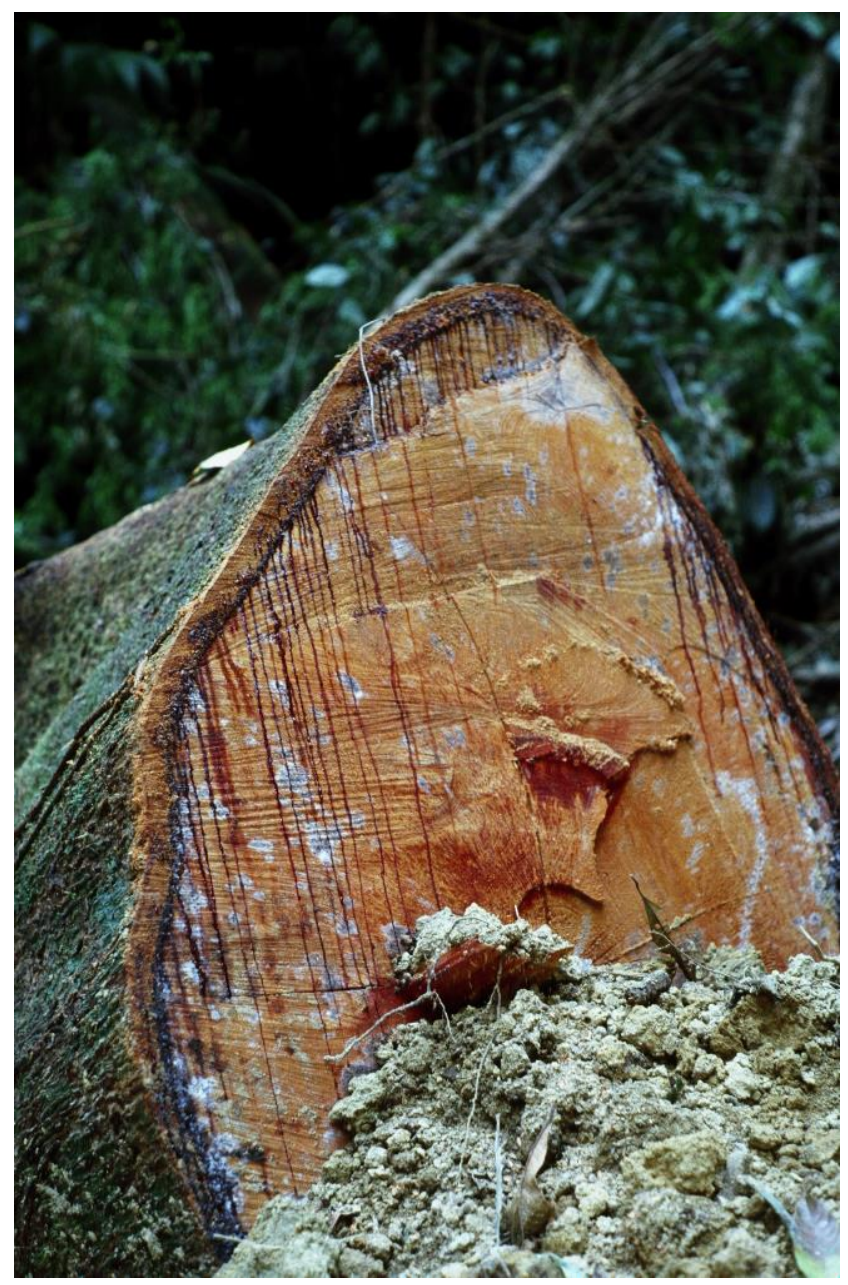

Figure 1. Virola koschnyi (sangre) is oozing sap at a Tela Industrial Maderera S.A. (TIMSA) logging site in 1979. This tree was estimated to be over 200 years old. The sandy soils are difficult to reforest. 
The third most utilized timber was ceibo or kapok (Ceiba pentandra: Malvaceae), which comprised $23 \%$ of the total wood extracted. Ceiba wood $\left(0.23 \mathrm{~g} / \mathrm{cm}^{3}\right)$ is about half as dense as Virola wood. Ceiba wood was used for the inside plywood layers. TIMSA kept no record of the locations where Ceiba, or any other trees, were harvested. Large Ceiba trees are scarce in the primary forests, but large Ceiba trees were frequent and readily visible in many north-coast pastures. This visibility allowed TIMSA to locate and harvest large Ceiba trees from pastures. It was easier to purchase trees from local landowners than to build an in-road to access an occasional Ceiba tree in the primary forest. Prior to the TIMSA logging operation it was easy to count dozens of large Ceiba in pastures, on both sides of the road, between San Pedro Sula and La Ceiba. It seemed that landowners had protected these majestic trees, sacred to the ancient Maya, as shade for livestock or for sentimental reasons. In the early 1980s, I saw 5 trees being removed by TIMSA. Many other Ceiba trees were also removed from pastures. In 2013, I counted only 10 Ceiba trees in roadside pastures between EI Progreso and Tela, most were small.

The fourth most exploited species was guanillo (Sterculia mexicana: Malvaceae), which comprised 6$7 \%$ of total wood extracted in eight years (Table 1). Like Ceiba, this less dense wood was used for the interior layers of plywood. Sterculia mexicana was one of several tree species from trees in this harvest area that was not known to occur in Honduras prior to this study (Hazlett 1979). This is an example of a tree that was exploited before it was known to occur in Honduras. Seeds from this tree species were collected and were planted into the Lancetilla arboretum in 1979 (Figure 2). In 2012 two guanillo trees planted in 1979 had a diameter of $61 \mathrm{~cm}$ (24 inches) and $36 \mathrm{~cm}$ (14 inches), an annual diameter increment of 0.7 to $1.0 \mathrm{~cm}$ per year (Figure 2). This species has less dense wood than Virola, which helped explain its more rapid growth.

The fifth most exploited species was barrenillo (Mortoniodendron anisophylum: Malvaceae), which comprised $3-4 \%$ of the total amount of wood extracted in eight years (Table 1). Prior to its use for plywood, this large tree was seldom collected in Honduras. It was not possible to verify the scientific name for this species, so its determination remains as probable. The $M$. anisophylum name is based on the common name barenillo, a name that is similar to barillo, a common name for Symphonia globulifera. It was determined, however, that the barrenillo cut by TIMSA was not $S$. globulifera.

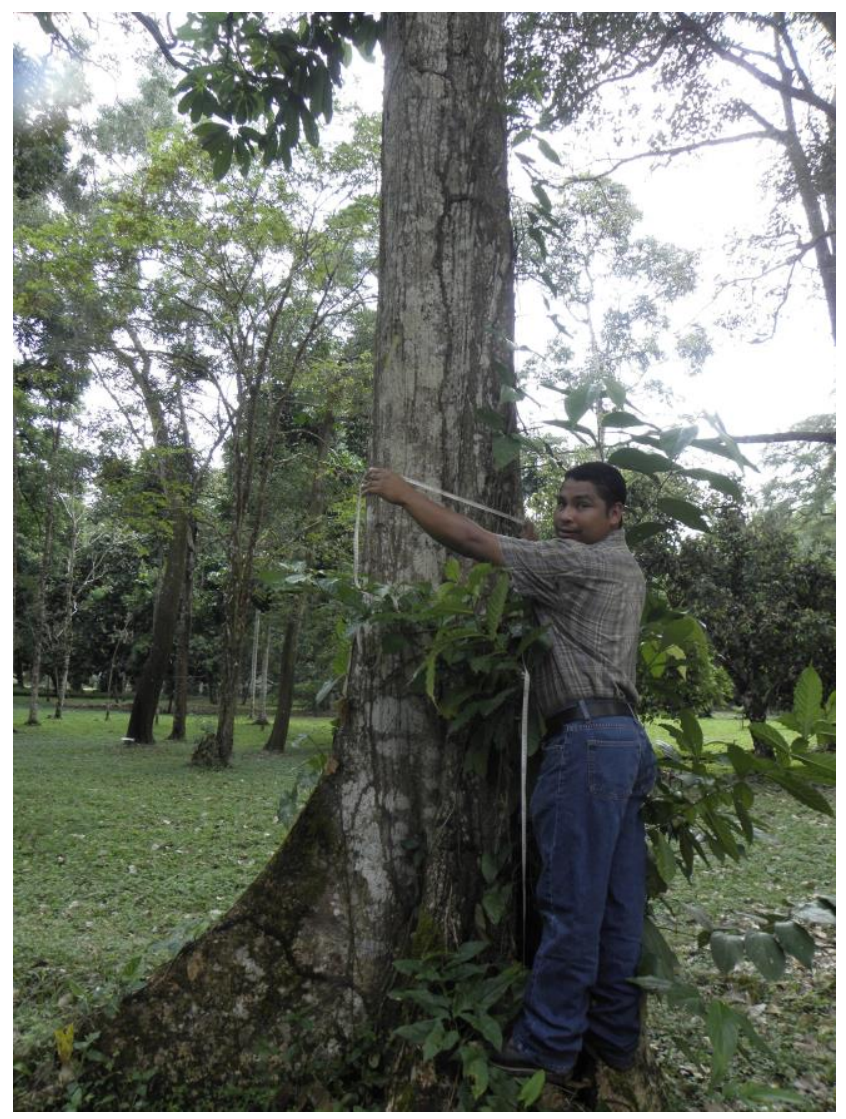

Figure 2. A Sterculia mexicana (guanillo) tree in the Lancetilla arboreum in 2012. This native tree, planted in 1979, grew from seeds collected in 1979 from the Tela Industrial Maderera S.A. (TIMSA) logging site. In 2012, this tree was $36 \mathrm{~cm}$ in diameter (dbh).

The sixth most exploited species was laurel (Cordia alliodora: Boraginaceae), which comprised $2-3 \%$ of the total amount of wood extracted in eight years (Table 1). This second-growth tree is well known and it is often utilized for its high quality lumber.

The above six trees comprised nearly $90 \%$ of the total volume of wood extracted from these forests over eight years. Each of the remaining 13 trees on Table 1 and 25 taxa on Table 2 contributed less than $1 \%$ to the total volume of wood extracted. Among these littleused species were readily identified trees from higher elevations, such as Juglans (nogal) and Podocarpus (ciprés de montaña). The identification of infrequently extracted trees was not possible because no leaf material was seen. A few infrequently harvested trees 
had common names, such as opiojante and retintón, that were previously unreported.

\section{Discussion}

Tree Common Names. The common names for most of the harvested timber species were consistently linked to scientific names (Tables 1 and 2). Common names that were not definitively verified to a scientific name are identified on these tables by an asterisk. A few of the common names for extracted timber species may have been recently contrived: for example, cuero de toro (bull hide), agujo (needle), retintón (a cracking sound), and gigante (gigantic). The cuero de toro name was said to refer to bark texture or to a tree with bark that is difficult to remove. The agujo name seemed to refer to Xylopia, a tree with spines on its trunk. The selfexplanatory name gigante suggested a large, but unknown tree. Finally, the unidentified retintón may refer to a tree that makes a cracking sound, perhaps when it is felled.

The best-known and most consistently used common name for a timber species in Honduras is caoba (mahogany). The caoba name has no literal translation, but it is believed to be a word from Taíno (indigenous Arawak peoples of the Caribbean). Austin (2004) reported that the English word mahogany may also be derived from Taíno words, in this case from mogno and maho, words that refer to strong fibers. The caoba name became well known soon after mahogany trees (Swietenia mahogonii) were exploited in the Antilles, especially in Cuba. The caoba name continued to be used when large stands of Swietenia macrophylla were discovered elsewhere, such as in British Honduras (now Belize) and in Honduras. The caobina common name for Virola is a marketing strategy, a descriptive name coined to link the lesserknown wood of Virola with that of the high-quality wood from caoba (mahogany).

The tempisque common name, used in this forest for Macrohasseltia macroterantha, is the same common name used for Sideroxylon capiri. Tempisque is derived from Náhuatl (tentl: lip and pitztic). These indigenous words may refer to sticky lips that can occur after you eat these fruits.

The common name azajarillo for the large Gordonia fruticosa (Theaceae) trees is the diminutive of azahar. The word azahar is derived from the Arabic word zahr (flower) and azzahár (white flower). Spanish use the word azahar for white, aromatic flowers, especially for the flowers of oranges, lemons, and other citrus. The diminutive name azajarillo (small azahar) appears to refer to the white, presumably aromatic flowers that seasonally fall to the ground from high in the canopy.

The cedar and cedro tree common names were imported from Europe. These names are used in the Bible for the Cedars of Lebanon (Cedrus). The word cedar is derived from Latin (cedrus) and Old French (cedre), a reference to aromatic and reddish wood. In temperate regions of the New World the cedar name became used for gymnosperms species with red, aromatic wood (Juniperus, Libocedrus, Tsuga). In Tropical America the cedro name was also applied to aromatic, red wood, but in this case it was for angiosperm, not for gymnosperm trees.

The best known and perhaps the first tropical American tree to be called cedro (or cedro real) is Cedrela odorata (Spanish or cigar-box cedar). The cedro name for Cedrela odorata (Meliaceae) became a model for the common names of other tropical trees. As in Europe and North America, a cedro derived common name in tropical America is used for trees with red, aromatic wood. Unlike in Europe and in North America, in tropical American the pinnately compound leaf type, the leaf type of Cedrela odorata, is also part of the model for other common names derived from cedro. Honduran trees with common names derived in this fashion include: cedro macho (Carapa guienensis: Meliaceae), cedro espino, teta (Zanthoxylum: Rutaceae), cedro negro (Juglans: Juglandaceae), cedrón (Quassia amara: Simaroubaceae), cedrillo (Mosquitoxylum jamaicense: Anacardiaceae) and the TIMSA harvested cedrillo (Huertea cubensis: Tapiscaceae). Similar common names for taxonomically different trees, all with pinnately compound leaves and reddish wood, is an example of a folk taxonomy based on leaf morphology and wood properties. It is also a compliment to the identification skills of local tree finders.

The cedrillo common name was known before botanists realized that Huertea cf. cubensis was present in Honduras (Hazlett 1981). As soon as cedrillo was identified as a quality timber species, a small plantation of Huertea was established in Lancetilla in 1979. In 2015, these 37 year old trees ranged in diameter from 12 to $16 \mathrm{~cm}$ (5 to 6 in) to 25 to $30 \mathrm{~cm}$ (10 to $12 \mathrm{in})$. This is a diameter increment of 0.3 to $0.8 \mathrm{~cm}$ per year, somewhat slower than the 0.7 to $1.0 \mathrm{~cm}$ annual diameter increment for two Sterculia mexicana trees and similar to the growth rate for a Virola. 
Other common names utilized by TIMSA workers would describe the fruit, sap, bark or wood of a tree. The masica name (Brosinium alicastrum) is from the Spanish word masa (flour, water and lime mixed to make dough). The masica tree has a fruit (breadnut) that has long been used, since Mayan times, to make a type of flour. The guanillo name is difficult to decipher. It appears to refer to a tree with relatively soft wood. It may be a modified diminutive of guarumo (Cecropia sp.), a tree with similarly lobed, but larger leaves. The agujo (needle) name refers to Xylosma, a tree with needle-like thorns on the trunk. I was told by TIMSA sawyers that cuero de toro (bull hide), a common name for Eschweilera hondurensis (and other trees), was based on the fact that its bark is difficult to remove. Bark texture may also be a reason of this common name, since species of Caprinus, Ulmus, and Cassipourea in Honduras are sometimes called cuero de toro (Nelson 2008). Trees in these genera have bark that may suggest a bull's hide. The amargoso (bitter) common name for Vatairea lundellii, a reference to the bitter taste of the wood from this tree, appears to be a well-established name.

Animals have inspired common names for trees. Among these is zorra (fox) for the bipinnately compound leaves of Jacaranda. With a bit of imagination, these leaves may resemble a foxtail. In like fashion, the compound leaves of Cupania may resemble a turkey tail (cola de pavo). Another tree with large compound leaves is Schizolobium parahyba. In this case, the tree is called tambor (drum), a name that may be associated with the use of its wood to make drums.

A large category of plant names for native tree species are those that refer to cultivated trees. For example, there are many native trees with common names derived from aguacate (Persea americana). Among these names are, aguacate de anís (Persea), aguacatón, agucatillo, aguacate colorado, aguacate negro, aguacate picapica (Ocotea sinuata), and aguacate de monte. Aguacate derived common names are not used only for one genus or species. They are often used for different Lauraceae genera, many of which are very similar in appearance. These genera include Persea, Nectandra, Ocotea, and Phoebe. Other examples are the well-known tropical fruit trees called nance (Byrsonima crassifolia), higos (Ficus spp.), sapote or zapote (Pouteria spp.), guayaba (Psidium guajaba), and níspero japonés (exotic Eriobotrya japonica). These names are often modified and used as names for native trees that look similar. A few examples are nance de montaña (Hyeronima alchorneoides), guayaba de danto (Chrysophyllum mexicanum), higuero (Ficus spp.) and zapotillo (Couepia polyandra).

Two large categories of plant common names are based on a tree use for carbón (charcoal) and Catholic saints. A rhyming Mexican poem recognizes these names and uses 'Hasta los palos del monte tienen su destinación; unos nacen para santos y otros para hacer carbón' (Mexican minstrel ca 1845). [English translation: Even the mountain trees have a destiny: Some are born to be saints - others to be charcoal.]

Many Honduran trees have common names based on their use as carbón (charcoal). Trees with carbón in their common name tend to have dense enough wood to make acceptable charcoal. Their common names can refer to the color, texture or shape of the charcoal. A few examples (Nelson 2008) are: carbón blanco, carbón de Comayagua or carbón chele (Mimosa tenuiflora: Fabaceae), carbón macho or carbón negro (Guarea glabra: Meliaceae) carbón montón (Matayba oppositifolia: Sapindaceae), carbonera (Consolida orientalis: Ranunculaceae), and carbonera del monte (Petrea volubilis: Verbenaceae). These trees are in different genera, different plant families, and often have other common names. This is a case where common names are based on use for charcoal production, not on vegetative morphology.

There are at least 15 Catholic saint names used for Honduran plants (Nelson 2008). These saints, with the number of plants with their name in parenthesis, include: San Antonio (4), San Andrés (3), San Carlos (3), Santa Catarina (2), Santa Elena (1), San José (1), Santa Lucia (2), San Martin (2), Santa Marta (7), San Ramón (1), Santa Rosa (1), Santa Teresa (2), and San Sebastian (2). Most of these are herbs or ornamental plants.

The two saints most often used for Honduran plants are Santa María (9) and San Juan (11). Given the importance of Santa María, mother of Jesus, it is not surprising that nine plants honor María. It is less clear why 11 plants, most of them trees, are named for San Juan (Saint John). Eight Honduran trees called San Juan, or a related name, are: San juan arenillo (Ilex discolor), San juan campano, San juan arenillo or San juan areno (Ilex tectonica), San Juanillo (Dendropanax arborea), San Juan de Costa or San Juan peludo (Vochysia ferruginia), San Juan de pozo, San Juan de agua or San Juan de charco (Vochysia guatemalensis), San Juan areno, San Juan arenillo or 
San Juan guayapeño (Tetrorchidium rotundatum), San Juan, San Juan sanpedrano (Tabebuia donnel-smithii), and San Juan (Tabebuia ochracea). Two herbs, both called San Juanillo, are Lobelia cardinalis and Bonellia macrocarpa. Also, Habenaria eustachya and Sobralia macrantha orchids are called San Juan.

The reason why the San Juan common name is so well represented is unclear. A closer look at this saint may help determine why this name is so popular. Saint Francis de Assisi is the patron saint of animals and nature, but there are no Mesoamerican plants named in his honor. Meanwhile, Saint John is the Saint for Charity, not necessarily a reason to honor plants or trees with his name. Early Spaniards may simply have had a fondness for Saint John.

Another possibility that could explain the frequent use of the San Juan name for plants relates to Hypericum perforatum (St. John's wort), a well-known European plant. This herb produces yellow flowers around June 24, a day that is celebrated in Spain by Catholics as St. John's birthday. Spaniards living in the New World may have remembered the association of St. John's day with yellow flowers. However, no yellow Hypericum perfoliatum were in the New World. Observant Spaniards may have assigned the San Juan names to various trees with yellow flowers, such as Vochysia and Tabebuia trees, that were in flower around the end of June. This speculative explanation does not explain the San Juan name for plants without yellow flowers.

Newly Discovered Trees. Plant collections from the primary forests harvested by TIMSA included new records for the Honduran flora and a previously undescribed species (Hazlett 1979). Among these were: 1) Guarea tonduzii D. DC. (Meliaceae), a tree which occurs from Mexico to South America; 2) Huertea cf. cubensis Griseb. (Tapisciaceae); 3) Lacmellea standleyi (Woodson) Monachino (Apocyaceae); 4) Meliosma anisophylla Standl \& L. Williams (Sabiaceae), an infrequent tree reported previously from Panama by Paul Allen (1956); 5) Mollinedia guatemalensis Perkins (Monimiaceae), a small tree which occurs in Mexico, Guatemala and Honduras; 6) Ormosia velutina Rudd. (Fabaceae), a tree with red and black seeds which occurs from Belize to Costa Rica, and 7) Sterculia mexicana R. BR. (Malvaceae). Huertea and Sterculia, exploited for timber, were discussed previously. The most unusual tree collected from this logged area was described as Haptanthus hazlettii.
Lacmellea standleyi (Apocynaceae) has been again collected from Atlántida (Pico Bonito) and from Yoro by Nelson and Evans after 1979. This tree has pyramidal spines on its trunk, edible fruits and palatable latex. It occurs in lowland forests from Belize to Colombia. In Colombia it is known as palo de vaca (cow tree), lechoso (milky), teta leche (milk teat: conical spines) or lechemiel (milk-honey). Indigenous settlers of Guahibos and Sikuanis in the silvan zones of Orinoquía eat Lacmellea fruits and drink its latex. The fruits are said to have a flavor reminiscent of mangos and are used in Colombia to make jellies, ice cream, and wine. Because of these uses, the chemical and nutritional value of Lacmellea standleyi has been investigated (Soto Chavarro et al. 2013). These authors reported that milk tree fruits were edible at all stages of development, but the fruit alkaloid content declined (less bitter) and lycopene contents increased as they ripened. The lechemiel name (milk-honey) is a reference to the sweet, milky sap that is consumed by people as a snack or whenever milk from domestic animals is in short supply. This use of this tree has not been studied in Honduras, but it is a candidate for plantation trials in the Lancetilla arboretum.

Endemic and Monotypic Haptanthus. The most interesting plant collected from the TIMSA logged area was a primitive angiosperm that was described as Hapthantus hazlettii. It took 30 years for this unusual and primitive tree to be correctly classified in the taxonomic hierarchy. It may still be moved to another evolutionary branch. I first collected this tree in a steep ravine in 1980. It was not seen again until 2010 (Shipunov and Shipunov 2011). Shipunov and Shipunov indicated that Haptanthus was first collected "almost by accident". They were unaware that this tree was very much collected on purpose. Even though lowland tropical forests have many tree species, it is often difficult to collect quality plant specimens. This is because flowers and fruits tend to be unavailable in a towering canopy. For this reason, field trips were arranged to visit recently logged areas, where canopy plant material from felled trees was more available.

On April 8, 1980, I collected flowering material of a tree, later to be named Haptanthus, from a small tree in a steep ravine. I spent most of the next day in an unsuccessful effort to assign it to a family. It did not key well, but my best guess was Euphorbiaceae. I thought it was unusual, because it had no petals, but I did not realize how unusual it really was. I made a trip a few months later to the Field Museum of Natural History in 
Chicago and to the Missouri Botanical Garden in St. Louis with the purpose to identify this tree. One of the botanists at Missouri thought the flowers were deformed because of disease, but they were not. I felt better when several very experienced tropical botanists were also unable to assign this plant to a family. I left this unique specimen at MBG and it was eventually sent to the Smithsonian herbarium for identification. Nine years later, it was described as Haptanthus hazlettii (Goldberg and Nelson 1989). Goldberg and Nelson considered it to be close to Euphorbiaceae or Buxaceae, but it did not fit well into either family. These authors suggested that it might merit its own family: Haptanthaceae. Everyone agreed Haptanthus was unique enough to be the only species in its newly established genus (monotypic). For this reason, it was also difficult to assign Haptanthus to any of the established plant families.

Once the scientific community was aware that Haptanthus existed, (1989), there was considerable interest in this tree. This interest was due in large part to the primitive floral characteristics of this plant. Among these were a monoecious habit, axillary flowers, opposite leaves, and no perianth. A complete description of $H$. hazletti follows:

\section{Taxonomic Description of Haptanthus hazlettii}

Habit: Plants monoecious. Shrubs or small trees, 5-8 $\mathrm{m}$. Stems 5-7, the lower arising ca $0.5 \mathrm{~m}$ above base, the larger 10-12 cm dbh. Branches arching, ca. $1 \mathrm{~m}$ long.

Leaves: Opposite, glabrous, mesophytic, venation pinnate, secondary veins somewhat impressed. Petioles 5-10 cm. Blades 10.0-13.5 × 4.0-5.6 cm, elliptic, base rounded, apex acuminate, margins entire.

Inflorescence: Inflorescence axillary, mostly of 1 central carpelate flower subtended by (0) 2-6 staminate branches. Flowers glabrous, greenish yellow; perianth absent. Carpelate flowers: Solitary or rarely 2 per node; $9-10 \mathrm{~mm}$ including $4-5 \mathrm{~mm}$ pedicel above $3.5-4.5 \mathrm{~mm}$ stipe, subtended by a whorl of deltoid bracts ca. $0.5 \times 1.0 \mathrm{~mm}$; style lacking; stigma lobes 3 and diverging, $3-4 \times$ ca. $1 \mathrm{~mm}$ but maturing to 5-6 $\mathrm{mm}$ in mature fruit and becoming brownish. Ovary unilocular; placentation parietal with 3 placentas; ovules 18-20. Staminate flowers: Subtending the central carpelate flower on 1-3 pedunculate branches; 6-7 mm long; stamens 2-6, sessile; filaments ca. $5 \mathrm{~mm}$, anthers ca. $2.5 \mathrm{~mm}$; the larger branches bearing stamens at 1-3 mm long internodes proximally in opposite arrangement but transitioning to alternate distally. Each stamen subtended by a solitary deltoid bract 0.5-1.0 $\mathrm{mm}$.

Fruits: Capsular, 45-60 × 10-12 mm, ellipsoid, bearing 3 equally-spaced rounded longitudinal ridges ca. 0.5$1.0 \mathrm{~mm}$ high; dehiscence is septicidal, into 3 valves, greenish. Seeds 2.5-3.0 × 3-4 mm, pyriform, corniculate, brownish.

Habitat: In steep ravines or riparian areas of lowland tropical forests 100 to $600 \mathrm{~m}$ elevation.

Taxonomic notes: An inflorescence may occur at up to 10 nodes per branch, with more inflorescences on branches well exposed to sunlight. Doust and Stevens (2005) suggested that the two flattened structures (ca. $1.0-1.4 \mathrm{~mm}$ ) at the apex of the anther are either tepals with bilocluar introrse stamens, or foliose introrse stamens. This unique structure is one reason Haptanthus is monotypic (having only one species in the genus), was given the name Haptanthus, and was proposed as Haptanthaceae, a monotypic family.

Since Haptanthus had traits hypothesized to occur only in very primitive angiosperms, there was much interest in finding more plant material. Within a month of the Goldberg and Nelson publication, I had several formal requests for Haptanthus plant material for anatomical and molecular studies. Those that made requests for material were unaware that only one tree of this species had ever been seen, nine years previously, and no fruits were known.

In an effort to find additional Haptanthus trees, especially fruits, I revisited the type location with Felix Coe in 1991. Felix and I went with "Chevo", an expert tree finder, to the exact steep ravine where this plant was first collected in 1980. Eleven years later, in 1991, this ravine had no trees and had been replaced by grass for a pasture. In addition, the land for several kilometers around this type location had also been deforested-disheartening to say the least. This entire area had been dense forest 11 years earlier. The inroads created by TIMSA had allowed ranchers and their cattle to access previously inaccessible areas. We searched many of the small forest patches and nearby ravines, but did not locate any Haptanthus trees. Another unsuccessful expedition to search for Haptanthus, funded by National Geographic Plant Exploration grant, was made by Allan Brant and myself 
in 1994. Honduras botanists also made excursions to this area, but none were successful. Haptanthus hazlettii was though to be extinct.

Despite the lack of more plant material, academic interest in Haptanthus continued. Goldberg and Alden (2005) closely examined the morphology and anatomy of herbarium specimens, but without more material they could not confidently assign it to any known plant family. Doust and Stevens (2005) also examined the available material and published a reinterpretation of its staminate flowers. Mabberley (2008) and Nelson Sutherland (2008) assigned Haptanthus hazlettii to Haptanthaceae, a monotypic plant family.

In 2010, two Haptanthus trees were rediscovered by Alexey Shipunov (2011). These were at a location called Matarras, about $1.0 \mathrm{~km}$ south of the type locality. He used images from Google Earth to identify patches of trees in ravines and riparian areas near the type location. Molecular analyses on collected plant material, still no fruits, led Shipunov to confirm that Haptanthus was a basal endicot (a primitive angiosperm), best assigned to a basal position in the Buxaceae (Shipunov and Shipunov 2011). Shipunov spent little time in Honduras, but he did encourage Ciro Navarro and Luis Bejarano from the Lancetilla Botanical Garden to continue the search for Haptanthus trees. In pursuit of this goal, Navarro and Bejarano met with local foresters, showed them photographs, and enlisted their help in the search for more individuals of this enigmatic species.

Local foresters were soon successful in finding additional Haptanthus populations. In 2010 Alonso Portillo located seven Haptanthus trees by a stream that enters into the Jilamito River - near the Texiguat protected area. Bejarano and Navarro went with Portillo to better explore the Jilamito area, and counted 24 trees. Also in 2010, Efraín Aguilar first located seven additional Haptanthus trees by a stream in Los Olivos (South of Mezapita). A subsequent visit by Aguilar with Arnaldo Contreras tallied six more trees for a total of 13 trees at this location. In 2011, Contreras found another five trees by a stream in La Sirena. The only trees with fruits were two of the trees at the La Sirena area. Since 2011 no additional trees have been reported. In 2012, including the two located by Shipunov, a total of 44 Haptanthus plants had been discovered. Two of the four known Haptanthus locations were monitored in 2014. Funding has not been available to monitor all sites in every year. The discovery of these additional Haptanthus trees and the first description of its fruits was published by Bejarano (2015). Bejarano also took photographs of trees, flowers, and fruits that were used to produce a botanical illustration of Haptanthus hazlettii (Figure 3).

As of 2015, only four small groups of Haptanthus trees are known. These have 2, 5, 13 and 24 individuals, for a total of only 44 trees. All four of these groups occur in Atlántida Department. Indeed, the long-term survival of this species is very uncertain. All four Haptanthus locations are within $12 \mathrm{~km}$ of each other. They occur in riparian areas along the Leán River (río Leán), the Mezapa River (río Mezapa) or along tributaries of these rivers.

The few remaining Haptanthus trees could easily be cut for firewood because they occur in small patches of forest surrounded by pastures. Minimal fruit production, observed for only 2 of 44 trees, places even more doubt on the long-term ability of Hapanthus to survive en situ. Meanwhile, nothing is known of its pollination biology: the identity of pollinators, (perhaps primitive insects), their abundance, mode of attraction, or effectiveness.

Academic interest in Haptanthus has diminished greatly since it was rediscovered in 2010. Since 2012, the chances have increased that Haptanthus will be extirpated from the few locations where it still occurs. If Haptanthus had not had primitive traits, of special interest among taxonomists, it would not have inspired the plant expeditions that led to its rediscovery.

There are at least 270 endemic plant species in Honduras (Nelson 2001). Many of these endemics are rare and of special interest, but very few have inspired botanical research or expeditions. This is in large part due to no or very little funding for botanical work in Honduras. Two Honduran endemic plant species, known only from their type collections, that have not yet had expeditions to relocate individuals are Stenanona hondurensis G.E Schatz, F.G. Coe \& Maas and Stenanona turbercula G.E. Schatz \& Maas (Annonaceae). These endemic species were collected while searching for Haptanthus. 


\section{Refugio de Vida Silvestre Texiguat, Honduras Cabeza de Negro (pico al fondo)}

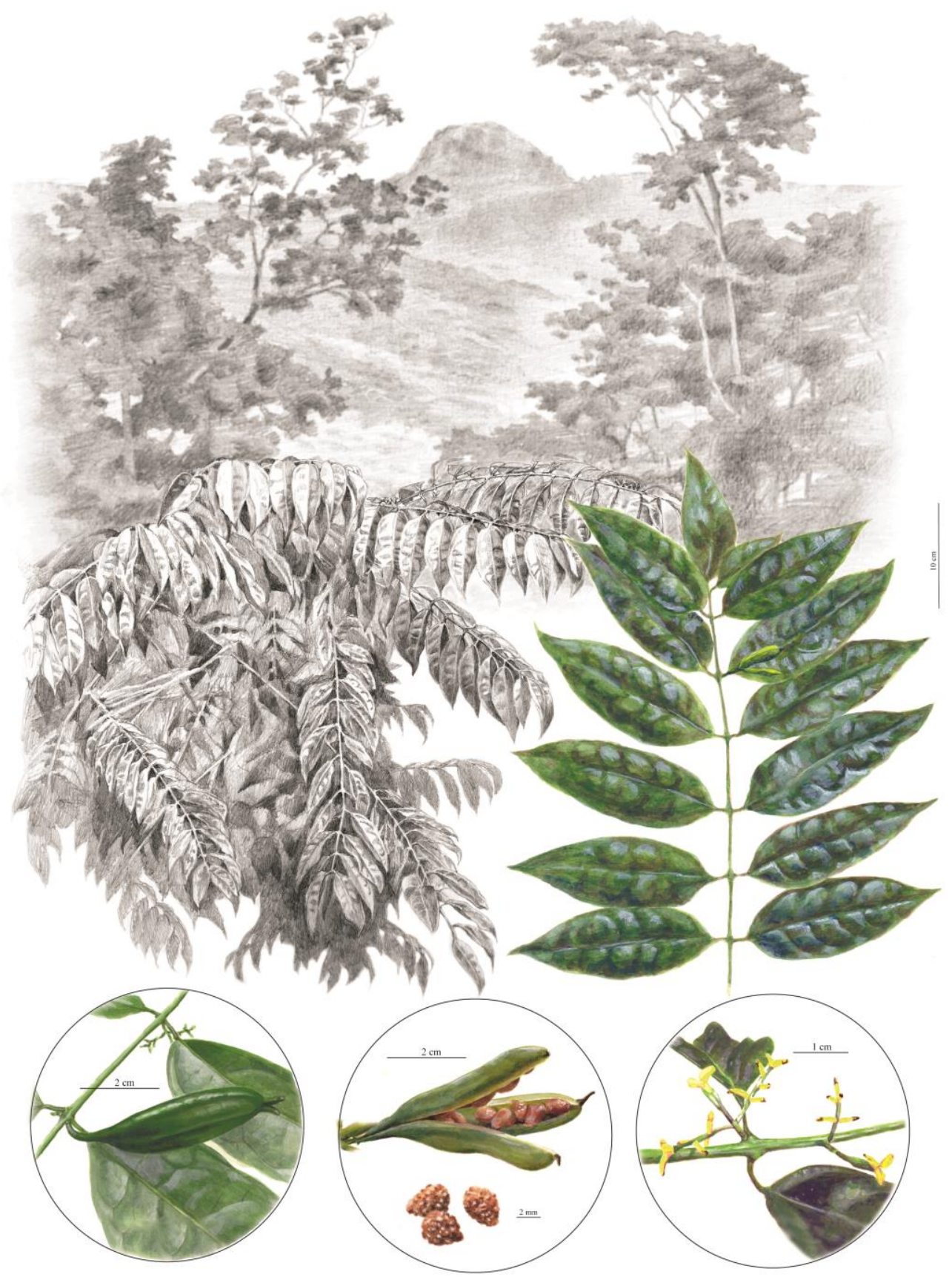

Haptanthus hazlettii Goldberg \& C. Nelson Árbol Enigmático de Atlántida

Figure 3. Botanical illustration of Haptanthus hazlettii with a background view of its location. Botanical illustration by Randy Raak, based on photographs by Luis Bejarano. 
Biologists agree that every living species is special, but conservation efforts tend to focus more on animals than on plants. In recent years, social unrest, minimal funding, and logistical difficulties have reduced biological research efforts in Honduras, especially for plants. Plants tend to generate more empathy if they are primitive, like Haptanthus and cycads, or are of economic importance.

Two Honduran endemics with ethnobotanical uses, species that deserve further study, are Monstera madreverde Grayum \& Karney (Araceae), an epiphyte from forests near San Juan Pueblo, Atlántida and Hondurodendron urceolatum C. Ulloa, Nickrent, Whitef. \& D. Kelly (Aptandraceae), a tree known only form Parque Nacional El Cusuco, Cortés. The Monstera epiphyte (Karney and Grayum 2010) has strong, flexible aerial roots that have been utilized for decades to weave baskets (mimbre). The Hondurodendron tree has an edible fruit that resembles a guayaba, a fruit that is known locally as guayabillo, guayabillo de montaña and guayaba de montaña. These two endemics are a high priority in terms of plant protection and research. These and other rare Honduran endemic plants could be better protected if they were introduced into the arboretum of the Lancetilla Botanical Garden. In 2015, a few Haptanthus hazlettii trees that were air-layered in wild populations, had young plants in the Lancetilla nursery. These plants are not yet able to survive without care.

\section{Summay}

The expanse of primary forests in the Atlántida Department of Honduras has diminished greatly since the early 1970s. This article has documented 50 tree taxa that were exploited for timber, including Huertea cubensis and Sterculia mexicana, species that were cut and utilized before botanists were aware they occurred in Honduras. Non-timber species collected from the TIMSA harvest area included the discovery of Haptanthus hazlettii, a primitive angiosperm species (Buxaceae).

The primitive Haptanthus was considered to be extinct, but was eventually rediscovered. Nonetheless, the long-term survival of Haptanthus, and other Honduras endemic plants, is very much in jeopardy. Deforestation is likely to extirpate some Honduran endemic plant species before they are discovered. Other Honduran endemics, especially those known only from one or a few collections, are likely to be extirpated before they are rediscovered.
Acknowledgements. I thank Luis Bejarano (botanist at The Escuela Nacional de Ciencias Forestales, Siguatepeque, Honduras) and Wilson Zuniga (botanist at Jardín Botánico de Lancetilla, Tela, Honduras) for their comments on early drafts of this paper. I thank Randy Rack (Denver, Colorado) for the excellent botanical illustration and Dr. Neil Snow for his quality edits to the taxonomic description for Haptanthus.

\section{Literature Cited}

Allen, P.H. 1956. The Rain Forests of Golfo Dulce. Stanford University Press, Stanford, CA.

Bejarano, L. 2015. Reporte y caracterización de poblaciones, fenología y descripción del fruto de Haptanthus hazlettii, una especie endémica de Honduras. Tatascán vol (25) 2. (submitted): Universidad: Escuela Nacional de Ciencias Forestales, Siguatepeque, Honduras. 31-41.

Butler, R. 1994-2006. Honduras: Environmental Profile. https://rainforest Mongoaby.com/deforestation/archive/Honduras/html. (visited August 19, 2014).

Doust, A.N. and P.F. Stevens. 2005. A reinterpretation of the staminate flowers of Haptanthus. Systematic Botany 30 (4): 779-785.

Goldberg, A. and H.A. Alden. 2005. Taxonomy of Haptanthus Goldberg \& C. Nelson. Systematic Botany 30:773-778.

Goldberg, A. and C.S. Nelson. 1989. Haptanthus, A New Dicotyledonous Genus from Honduras. Systematic Botany 14:16-19.

Hazlett, D.L. 1979. Árboles Maderables y otros Árboles Desconocidos de la Cordillera Nombre de Dios. Ceiba 23 (2): $76-84$

Hazlett, D.L. 1981. Change in Structure, Growth and Decomposition during Succession in a Species-Rich Forest in Honduras. Ph.D. Dissertation, College of Forest Resources, University of Washington, Seattle. $196 \mathrm{p}$.

Grainger, A. 1993. Rates of Deforestation in the Humid Tropics: Estimates and Measurements. The Geographical Journal 159 (1): 33-44.

Kaimowitz, D. 1996. Livestock and Deforestation in Central America in the 1980s and 1990s: A Policy Perspective. Special Publication: Center for International Forestry Resources (CIFOR), Jakarta, Indonesia.

Karney, A.P. and M.H. Grayum. 2012. A New Monstera Species (Araceae) of Economic Importance from Honduras. Economic Botany 66(2): 207-213.

Mabberley, D.J. 2008. Mabberley's Plant-Book: A portable dictionary of plants, their classification and uses. 3rd Ed. Cambridge University Press, Cambridge, UK.

Nelson Sutherland, C.H. 2001. Plantas descritas originalmente de Honduras y sus nomenclaturas equivalentes actuales. Ceiba 42: 1-71. 
Nelson Sutherland, C.H. 2008. Catálogo de las Plantas Vasculares de Honduras. Espermatofitas. Editorial Guaymuras, Tegucigalpa, Honduras: Secretaria de Recursos Naturales y Ambiente.

Shipunov, A. and E. Shipunov. 2011. Haptanthus story: Rediscovery of enigmatic flowering plant from Honduras. American Journal of Applied Botany 98 (4): 761-763.

Soto Chavarro, E.L., A.M. Chicué, E. Murillo Perea and J.J. Méndez Arteaga. 2013. Bioprospecting of Lacmellea standleyi fruits (lechemiel), Revista Cubana de Plantas Medicinales 18(3): 412-430.
Ulloa, C., D.L. Nickrent, C. Whitfoord and D.L. Kellyn. 2010. Hondurodendron: A New Monotypic Genus of Aptandraceae. Annals of the Missouri Botanical Garden. 97: 457-467.

Recibido para publicación el 19 de mayo de 2015.

Aceptado para publicación el 3 de noviembre del 2015. 